\title{
ANTI-INFLAMMATORY ACTIVITY OF ETHANOLIC EXTRACT OF AZADIRACHTA INDICA LEAVES ON EXPERIMENTAL ANIMAL MODELS
}

\author{
Geetamoni Dutta ${ }^{1}$, Chinmoyee Deori², Swarnamoni Das ${ }^{3}$
}

${ }_{1}^{1}$ Assistant Professor, Department of Pharmacology, Assam Medical College and Hospital, Dibrugarh, Assam. ${ }^{2}$ Associate Professor, Department of Pharmacology, Assam Medical College and Hospital, Dibrugarh, Assam. ${ }^{3}$ Professor, Department of Pharmacology, Assam Medical College and Hospital, Dibrugarh, Assam.

\section{ABSTRACT}

\section{BACKGROUND}

To study the anti-inflammatory action of ethanolic extract of Azadirachta indica (EEAI) leaves on experimental animal models (both acute and chronic).

\section{MATERIALS AND METHODS}

The extract of Azadirachta indica leaves was prepared by percolation method using 95\% ethanol. Acute oral toxicity test of the extract was performed as per OECD 423 guidelines. Acute inflammation was studied by carrageenan-induced rat paw oedema method and paw volumes were measured plethysmometrically at one hour interval for 4 hours. Activity against chronic inflammation was studied by Freund's complete adjuvant induced arthritis method. Paw volumes were measured on $1^{\text {st }}$ day, $5^{\text {th }}$ day (injected paws) and on 21st day (non-injected paw). Aspirin $100 \mathrm{mg} / \mathrm{kg}$ was taken as the standard drug. A control group is maintained in both the models.

\section{RESULTS}

The results were analysed by ANOVA followed by Dunnett's multiple comparison test. EEAI in doses of $200,400 \mathrm{and} 800 \mathrm{mg} / \mathrm{kg}$ produced dose-dependent and significant $(\mathrm{p}<0.05)$ reduction of paw oedema in carrageenan-induced acute inflammation in comparison to control. EEAI also found effective in chronic arthritis model in dose dependent manner.

\section{CONCLUSION}

The present study indicates that EEAI has significant anti-inflammatory activity in both the models.

\section{KEYWORDS}

Azadirachta Indica, Carrageenan, Adjuvant Induced Arthritis, Anti-Inflammatory Activity.

HOW TO CITE THIS ARTICLE: Dutta G, Deori C, Das S.Anti-inflammatory activity of ethanolic extract of Azadirachta indica leaves on experimental animal models. J. Evolution Med. Dent. Sci. 2016;5(85):6335-6338, DOI: 10.14260/Jemds/2016/1431

\begin{tabular}{|c|c|}
\hline $\begin{array}{l}\text { BACKGROUND } \\
\text { Inflammation is a reaction in vascularised tissue to an } \\
\text { infection, irritation or foreign substances which cause cell } \\
\text { injury.[1] } \\
\text { The processes of inflammation consists of, (i) Dilatation } \\
\text { and increased capillary permeability, (ii) Emigration of } \\
\text { leucocytes and cellular infiltration, (iii) Proliferation of } \\
\text { fibroblasts and synthesis of new connective tissues. }{ }^{2}\end{array}$ & $\begin{array}{l}\text { Various extracts of neem leaves have been reported to } \\
\text { possess anti-microbial, anti-hyperglycaemic, }{ }^{5} \text { analgesic, } \\
\text { antipyretic }{ }^{7} \text { and hepatoprotective activity. }{ }^{8} \text { There is not much } \\
\text { information regarding the anti-inflammatory activity of its } \\
\text { leaf extract. Therefore, the present study was undertaken to } \\
\text { evaluate anti-inflammatory activity of Azadirachta indica } \\
\text { alcoholic leaf extract on carrageenan-induced rat paw } \\
\text { oedema and adjuvant induced chronic arthritis in rat. }\end{array}$ \\
\hline
\end{tabular}

Medicinal plants play a key role in human health care. Azadirachta indica (Family Meliaceae; Assamese, Bengali Neem) is an evergreen indigenous plant widely available in India and Burma. Different parts of this plant have been traditionally used to treat skin diseases, ulcers, helminthiasis, diabetes, rheumatism and general weakness.[3] Active constituents isolated from the plant are the alkaloids, sterols, diterpenes, polyphenols, flavonoids, sesquiterpene lactones, etc. [4]

Financial or Other, Competing Interest: None.

Submission 17-09-2016, Peer Review 11-10-2016,

Acceptance 17-10-2016, Published 24-10-2016.

Corresponding Author:

Dr. Geetamoni Dutta,

Assistant Professor,

Department of Pharmacology,

Assam Medical College \& Hospital,

Dibrugarh-786002, Assam.

E-mail: duttageeta30@gmail.com

DOI: $10.14260 /$ jemds $/ 2016 / 1431$

\section{MATERIALS AND METHODS}

\section{Plant Material}

The study was carried out in the Department of Pharmacology, Assam Medical College and Hospital, Dibrugarh. Fresh matured leaves of A. indica were collected from the college campus and authenticated by Prof. L. R. Saikia, Department of Life Sciences, Dibrugarh University, Assam (Voucher Specimen No. DULSc 449).

\section{Plant Extract}

The leaves were cleaned, shade dried and powdered by electrical grinder; 300 gms of powdered leaves were extracted by percolation at room temperature with $95 \%$ ethanol. ${ }^{9}$ The extract thus obtained was concentrated by using controlled temperature (bath temperature $40-50^{\circ} \mathrm{C}$ ) and finally dried in a vacuum desiccator. The yield at the end of extraction was $15 \mathrm{gm}$. The extract of A. indica was administered orally as a suspension in $3 \%$ gum acacia to the rats. 


\section{Animals}

Healthy albino rats of Wistar strain of either sex weighing 150-200 gm each were procured from the Central Animal House, Assam Medical College and Hospital, Dibrugarh, Assam. The study was conducted in accordance with CPCSEA (Committee for the Purpose of Control and Supervision of Experiment on Animals) guidelines and the study was approved by the Institutional Animal Ethics Committee (Registration No. -634/02/a/CPCSEA). Rats were kept on standard laboratory diet and water ad libitum.

\section{Acute Oral Toxicity Study}

Acute toxicity test was performed for the ethanolic extract of Azadirachta indica following OECD 423 guidelines. ${ }^{10}$ As no mortality was recorded up to maximum dose of $2000 \mathrm{mg} / \mathrm{kg}$. Hence, $1 / 10^{\text {th }}$ of the maximum dose, i.e. $200 \mathrm{mg} / \mathrm{kg}$ is selected as minimum dose for the study.

\section{Anti-Inflammatory Studies}

For each experiment, the animals were divided into 5 groups with 6 animals in each group.

- Group A (control) received 3\% gum acacia $10 \mathrm{~mL} / \mathrm{kg}$ p.o.

- Group B1 (Test) received EEAI leaf extract $200 \mathrm{mg} / \mathrm{kg}$ p.o.

- Group B2 (Test) received EEAI leaf extract $400 \mathrm{mg} / \mathrm{kg}$ p.o.

- Group B3 (Test) received EEAI leaf extract $800 \mathrm{mg} / \mathrm{kg}$ p.o.

- Group C (standard) received aspirin $100 \mathrm{mg} / \mathrm{kg}$ p.o.

\section{Anti-Inflammatory Study Against Acute Inflammation}

Acute inflammation was produced by subplantar injection of $0.1 \mathrm{~mL}$ of freshly prepared $1 \%$ carrageenan suspension in normal saline in the right hind paw of the rats. ${ }^{11}$ Paw volume was measured plethysmometrically as described by Chattopadhyay et al at ' 0 ' hour and then at the end of 1 st, $2^{\text {nd }}$, $3^{\text {rd }}$ and $4^{\text {th }}$ after carrageenan injection. ${ }^{10}$ The volume of oedema was recorded as the difference between the paw volume at ' 0 ' hour and at the end of each hour. The drugs were administered orally in the respective groups one hour before carrageenan injection. The percentage inhibition of the rat paw oedema was calculated after each hour of carrageenan injection up to 4 hours by the following formula. ${ }^{12}$

$\%$ inhibition $=\frac{\text { (Control mean-treated mean })}{\text { Control mean }} \times 100$
The data were statistically analysed using ANOVA (OneWay analysis of variance) followed by Dunnett's multiple comparison test. $\mathrm{P}$ values $<0.05$ were considered significant.

\section{Study of Anti-Inflammatory Action in Chronic Inflammation}

The anti-inflammatory activity of EEAI against chronic inflammation was tested by Freund's adjuvant-induced arthritis method in rats. ${ }^{13}$ On $1^{\text {st }}$ day, $0.1 \mathrm{~mL}$ of complete Freund's adjuvant is injected into the subplantar region of the right hind paw of the rats. Treatment with the test and standard drugs to the respective groups was started on the same day and continued for 12 days. The paw volume on both sides was measured plethysmographically on the day of injection. The body weight of the rats was also recorded on the first day. On $5^{\text {th }}$ day, the volume of the injected paw was measured again indicating the primary lesion and the effect of the therapeutic agent on this phase. The severity of the induced adjuvant disease was followed by measurement of the volume in non-injected paw (secondary lesions) with a plethysmometer. Purposely, from day 13 to 21, the animals were not administered with the test drug or the standard. On day 21 , the non-injected paw volume and the body weight were determined again[13] and the polyarthritis severity was graded on a scale of $0-4$ : $0=$ no swelling; $1=$ isolated phalanx joint involvement; 2 = involvement of phalanx joint and digits; 3 = involvement of the entire region down to the ankle; 4 = involvement of entire paw including ankle. The maximum joint score was 12 including 3 secondary arthritis paws for each rat.[14]

1. For primary lesions: The percentage inhibition of paw volume of the injected right paw over control was measured at day 5 .

2. For secondary lesions: The percentage inhibition of paw volume of non-injected left paw over control was measured at day 21.

An Arthritis index was calculated as the sum of the scores as indicated above for each animal.[13]

Statistical Analysis was done using one-way ANOVA followed by Dunnett's multiple comparison test. $P$ value $<0.05$ was considered as significant.

\begin{tabular}{|c|c|c|c|c|c|c|}
\hline \multirow{2}{*}{ Group } & \multirow{2}{*}{ Drug } & \multirow{2}{*}{$\begin{array}{c}\text { Dose, Oral, Single } \\
\text { Dose }\end{array}$} & \multicolumn{4}{|c|}{ Mean Increase in Paw Oedema $($ Mean \pm SEM) in $\mathrm{mL}$} \\
\hline & & & $1^{\text {st }} \mathbf{h r}$. & 2nd $^{\text {hr. }}$ & $3^{\text {rd hr. }}$ & $\mathbf{4}^{\text {th }} \mathbf{h r}$. \\
\hline $\begin{array}{c}\mathrm{A} \\
\text { (CONTROL) } \\
\end{array}$ & $\begin{array}{c}3 \% \text { gum } \\
\text { acacia }\end{array}$ & $10 \mathrm{~mL} / \mathrm{kg}$ & $\begin{array}{c}0.36 \pm 0.04 \\
(-)\end{array}$ & $\begin{array}{c}0.43 \pm 0.05 \\
(-)\end{array}$ & $\begin{array}{c}0.46 \pm 0.05 \\
(-)\end{array}$ & $\begin{array}{c}0.49 \pm 0.05 \\
(-)\end{array}$ \\
\hline B1 & EEAI & $200 \mathrm{mg} / \mathrm{kg}$ & $\begin{array}{c}0.29 \pm 0.01 \\
(13.6 \%)\end{array}$ & $\begin{array}{c}0.32 \pm 0.01^{\mathrm{a}} \\
(20.1 \%)\end{array}$ & $\begin{array}{c}0.34 \pm 0.02^{\mathrm{b}} \\
(20.9 \%)\end{array}$ & $\begin{array}{c}0.35 \pm 0.02^{\mathrm{a}} \\
(22.6 \%)\end{array}$ \\
\hline B2 & EEAI & $400 \mathrm{mg} / \mathrm{kg}$ & $\begin{array}{c}0.23 \pm 0.01^{\mathrm{a}} \\
(33.2 \%)\end{array}$ & $\begin{array}{c}0.26 \pm 0.01^{\mathrm{a}} \\
(36.3 \%)\end{array}$ & $\begin{array}{c}0.23 \pm 0.01^{a} \\
(47.3 \%)\end{array}$ & $\begin{array}{c}0.21 \pm 0.01^{\mathrm{a}} \\
(53.5 \%)\end{array}$ \\
\hline B3 & EEAI & $800 \mathrm{mg} / \mathrm{kg}$ & $\begin{array}{c}0.22 \pm 0.01 \mathrm{a} \\
(37.9 \%)\end{array}$ & $\begin{array}{c}0.24 \pm 0.01^{\mathrm{a}} \\
(41.9 \%)\end{array}$ & $\begin{array}{c}0.21 \pm 0.01^{a} \\
(52.9 \%)\end{array}$ & $\begin{array}{c}0.20 \pm 0.01^{\mathrm{a}} \\
(58.1 \%)\end{array}$ \\
\hline C (STANDARD) & Aspirin & $100 \mathrm{mg} / \mathrm{kg}$ & $\begin{array}{c}0.20 \pm 0.01^{\mathrm{a}} \\
(40.6 \%)\end{array}$ & $\begin{array}{c}0.22 \pm 0.01^{\mathrm{a}} \\
(44.7 \%)\end{array}$ & $\begin{array}{c}0.18 \pm 0.01^{\mathrm{a}} \\
(59.6 \%)\end{array}$ & $\begin{array}{c}0.16 \pm 0.01^{\mathrm{a}} \\
(65.8 \%)\end{array}$ \\
\hline \multirow{3}{*}{\multicolumn{2}{|c|}{ One-Way ANOVA }} & $\mathrm{F}$ & 12.5 & 12.5 & 22.22 & 35.94 \\
\hline & & Df & 4,25 & 4,25 & 4,25 & 4,25 \\
\hline & & ap & $<0.05$ & $<0.05$ & $<0.05$ & $<0.05$ \\
\hline
\end{tabular}

$\mathrm{n}=6$ rats in each group. Figures in the parentheses indicate the percentage inhibition of paw oedema. (-) indicates no inhibition. ${ }^{a} \mathrm{p}<0.05$ when compared to control. One-Way ANOVA followed by Dunnett's multiple comparison test is done. 


\begin{tabular}{|c|c|c|c|c|c|c|}
\hline \multirow[t]{3}{*}{ Group } & \multirow[t]{3}{*}{ Drug } & \multirow[t]{3}{*}{ Dose } & \multirow{2}{*}{\multicolumn{2}{|c|}{$\begin{array}{c}\text { Mean Increase in Paw Volume } \\
\text { (mean } \pm \text { SEM) in mL } \\
\text { (\% Inhibition in Parentheses) } \\
\text { Injected Non-Injected Paw } \\
\end{array}$}} & \multirow{3}{*}{$\begin{array}{c}\text { Weight Change on } 21^{\text {st }} \\
\text { Day } \\
\text { (\% Change in } \\
\text { Parentheses) }\end{array}$} & \multirow[t]{3}{*}{$\begin{array}{l}\text { Arthritis } \\
\text { Index }\end{array}$} \\
\hline & & & & & & \\
\hline & & & on $5^{\text {th }}$ day & On 21st day & & \\
\hline A & $\begin{array}{l}\text { Control } \\
\text { (3\% gum } \\
\text { acacia) }\end{array}$ & $\begin{array}{c}10 \\
\mathrm{~mL} / \mathrm{kg}\end{array}$ & $\begin{array}{c}0.91 \pm 0.02 \\
(-)\end{array}$ & $\begin{array}{c}0.52 \pm 0.02 \\
(-)\end{array}$ & $-28 \pm 0.32$ & $7.8 \pm 0.24$ \\
\hline B1 & EEAI & $\begin{array}{c}200 \\
\mathrm{mg} / \mathrm{kg}\end{array}$ & $\begin{array}{c}0.71 \pm 0.03^{a} \\
(22 \%)\end{array}$ & $\begin{array}{c}0.20 \pm 0.02 \text { a } \\
(62.14 \%)\end{array}$ & $\begin{array}{c}-15 \pm 0.21 \mathrm{a} \\
(46.42 \%)\end{array}$ & $5.9 \pm 0.16^{\mathrm{a}}$ \\
\hline B2 & EEAI & $\begin{array}{c}400 \\
\mathrm{mg} / \mathrm{kg}\end{array}$ & $\begin{array}{c}0.64 \pm 0.12^{\mathrm{a}} \\
(29.80 \%)\end{array}$ & $\begin{array}{c}0.15 \pm 0.04 \text { a } \\
(71.15 \%)\end{array}$ & $\begin{array}{c}-10 \pm 0.3^{a} \\
(64.28)\end{array}$ & $5.1 \pm 0.12^{\mathrm{a}}$ \\
\hline B3 & EEAI & $\begin{array}{c}800 \\
\mathrm{mg} / \mathrm{kg}\end{array}$ & $\begin{array}{c}0.58 \pm 0.02^{\mathrm{a}} \\
(36.2 \%)\end{array}$ & $\begin{array}{c}0.12 \pm 0.02^{\mathrm{a}} \\
(76.92 \%)\end{array}$ & $\begin{array}{c}-7 \pm 0.31^{a} \\
(75 \%)\end{array}$ & $4.5 \pm 0.14^{\mathrm{a}}$ \\
\hline $\mathrm{C}$ & ASPIRIN & $\begin{array}{c}100 \\
\mathrm{mg} / \mathrm{kg}\end{array}$ & $\begin{array}{c}0.56 \pm 0.02^{\mathrm{a}} \\
(39.18)\end{array}$ & $\begin{array}{c}0.11 \pm 0.02^{\mathrm{a}} \\
(80.67 \%)\end{array}$ & $\begin{array}{l}-5 \pm 0.14 \mathrm{a} \\
(82.14 \%)\end{array}$ & $3.2 \pm 0.10^{\mathrm{a}}$ \\
\hline $\begin{array}{c}\text { One-Way } \\
\text { ANOVA }\end{array}$ & & $\begin{array}{l}\mathrm{F} \\
\mathrm{df} \\
\mathrm{Pa}\end{array}$ & $\begin{array}{c}182.8 \\
4,25 \\
<0.05\end{array}$ & $\begin{array}{c}82.36 \\
4,25 \\
<0.05\end{array}$ & $\begin{array}{c}66.80 \\
4,25 \\
<0.05\end{array}$ & $\begin{array}{c}96.32 \\
4,25 \\
<0.05\end{array}$ \\
\hline
\end{tabular}

$\mathrm{n}=6$ rats in each group. $(-)$ indicates no inhibition. ap $<0.05$ when compared to control. One-Way ANOVA followed by Dunnett's multiple comparison test is done.

\section{DISCUSSION}

Carrageenan-induced hind paw oedema in rats is the standard model of acute inflammation. It is a biphasic response. The first phase is mediated through release of histamine, serotonin and kinins, whereas the second phase is related to the release of prostaglandin-like substances which peak at 3 hours. ${ }^{15}$ The results of the present study suggests that EEAI in doses of 200, 400 and $800 \mathrm{mg} / \mathrm{kg}$ significantly suppressed carrageenan-induced paw oedema in rats when compared to control. Maximum anti-inflammatory activity was observed at $3^{\text {rd }}$ and $4^{\text {th }}$ hours of carrageenan injection. The probable cause of anti-inflammatory action EEAI in acute inflammation might be due to the inhibition of some of the mediator release within 3 hours of carrageenan injection.

Freund's complete adjuvant-induced arthritis is a widely used model of chronic inflammation. This model is widely utilised because of the strong correlation between the efficacy of therapeutic agents used in this model and in rheumatic arthritis in human. EEAI in all doses significantly reduced adjuvant induced paw oedema. The leaves of Azadirachta indica are rich in flavonoids. Flavonoids have demonstrated significant anti-inflammatory activity. ${ }^{16}$ Hence, anti-inflammatory action of EEAI might be due to the action of flavonoids.

Adjuvant induced arthritis is characterised by increased production of proinflammatory cytokines such as tumour necrosis factor- $\alpha$ (TNF- $\alpha$ ) and interleukin-1 (IL-1) associated with loss of body weight.17 These cytokines influence the hormones that regulate metabolism and also act directly on the target organs like muscle, liver, gut and brain. ${ }^{18}$ Thus, arthritis induced reduction in body weight can be prevented by EEAI and it might be due to inhibition of TNF- $\alpha$ and interleukin-1.

\section{CONCLUSION}

The leaves of Azadirachta indica has showed significant antiinflammatory activity against both acute and chronic inflammation models at all the tested doses establishing its traditional use in acute inflammatory conditions and rheumatism. Hence, further studies are required to establish and elaborate its molecular mechanism and proper clinical utility.

\section{ACKNOWLEDGEMENTS}

We are thankful to Prof. L. R. Saikia, Department of Life Sciences, Dibrugarh University for helping us with taxonomical identification of the plant. We are also thankful to the faculty and laboratory staff members of Pharmacology Department of Assam Medical College and Hospital, Dibrugarh for their support and encouragement.

\section{REFERENCES}

1. Cotran RS, Kumar V, Collins T. Acute and chronic inflammation. Robbins pathological basis of disease. $7^{\text {th }}$ edn. WB Saunders Company 1999:52-77.

2. Ghosh MN. Evaluation of anti-inflammatory drugs. Fundamentals of experimental pharmacology. $2^{\text {nd }}$ edn. Calcutta: Scientific Book Agency 1984:146-147.

3. Chopra RN, Nayar SL, Chopra IC, et al. Azadirachta indica (Meliaceae). Glossary of Indian medicinal plant. New Delhi: Council of Scientific and Industrial Research 1956:p. 31.

4. Govindachari TR. Chemical and biological investigations on Azadirachta indica (the neem tree). Curr Sci 1992;63(3):117-122.

5. Venugopal PV, Venugopal TV. Antidermatophytic activity of neem (Azadirachta indica) leaves in vitro. Indian J Pharmacol 1994;26(2):141-143.

6. Khosla P, Bhanwra S, Singh J, et al. A study of hypoglycaemic effects of Azadirachta indica (neem) in normal and alloxan diabetic rabbits. Indian J Physiol Pharmacol 2000;44(1):69-74.

7. Khanna M, Goswami M, Sen P, et al. Antinociceptive action of Azadirachta indica (neem) in mice: possible mechanisms involved. Indian J Exp Biol 1995;33(11):848850. 


\section{Jemds.com}

8. Bhanwra S, Singh J, Khosla P. Effect of Azadirachta indica (neem) leaf aqueous extract on paracetamol-induced liver damage in rats. Indian $\mathrm{J}$ Physiol Pharmacol 2000;44(1):64-68.

9. Remington. Solution, emulsion, suspension and extracts. The science and practice of pharmacy. 19th edn. Pennsylvania: Mack publishing company 1995:14951523.

10. OECD. In: Acute oral toxicity-acute oral toxic class method. Guideline 423, (adopted23/06/1996) eleventh addendum to the OECD guidelines for testing of chemicals, organization for economic co-operation and develpoment: Paris, 2001.

http://w.w.w.research.murdoch.edu.au/ethics/arec/oral toxicity.

11. Chattopadhyay RN, Chattopadhyay RR, Roy S, et al. A simple method for plethysmometric measurement of paw volume of small laboratory animals in the evaluation of anti-inflammatory effect. Bull Calcutta Sch Trop Med 1986;36:5-8.

12. Olajide OA, Awe SO, Makinde JM, et al. Studies on the antiinflammatory, antipyretic and analgesic properties of Alstonia boonei stem bark. J Ethnopharmacol 2000;71(12):179-86.

\section{Original Research Article}

13. Vogel HG. Antiarthrotic and immunomodulatory activity. Drug discovery and evaluation. Completely revised and enlarged. $2^{\text {nd }}$ edn. Germany: Springer publishing 2002:802-5.

14. Gu WZ, Brandwein SR. Inhibition of type-II collageninduced arthritis in rats by triptolide. Int $\mathrm{J}$ Immunopharmacol 1998;20(8):389-400.

15. Vinegar R, Schreiber W, Hugo R. Biphasic development of carrageenin edema in rats. J Pharmacol Exp Ther 1969;166(1):96-103.

16. Brasseur T. Anti-inflammatory properties of flavonoids. J Pharm Belg 1989;44(3):235-41.

17. Roubenoff R, Freeman LM, Smith DE, et al. Adjuvant arthritis as a model of inflammatory cachexia. Arth Rheum 1997;40(3):534-9.

18. Pomposelli JJ, Flores EA, Bistrian BR. Role of biochemical mediators in clinical nutrition and surgical metabolism. J Parenter Enteral Nutr 1998;12(2):212-18. 